\title{
Rate and Time of Boron Application Increase Almond Productivity and Tissue Boron Concentration
}

\author{
Agnes M.S. Nyomora and Patrick H. Brown \\ Department of Pomology, University of California, Davis, CA 95616-8683 \\ Bill Krueger \\ Cooperative Extension, University of California, Orland, CA 95963 \\ Additional index words. flowering, fertilization, nut set, Prunus dulcis
}

\begin{abstract}
Previous studies with tree species have demonstrated that foliar boron (B) promotes flowering, fruit set, and yield. However, for most species the optimum time for foliar B application has not been determined. This investigation was undertaken to study the effects of time and rate of $B$ application on almond [Prunus dulcis (Mill D.A.Webb)] tissue $B$ concentration, fruit set, and yield. Solubor $\left(\mathrm{Na}_{2} \mathrm{~B}_{8} \mathrm{O}_{13} \cdot 4 \mathrm{H}_{2} \mathrm{O}\right)$, a commercial product containing $20.5 \% \mathrm{~B}$, was applied with a handgun sprayer either in September (3 weeks postharvest), December (dormancy), or February (budbreak) at rates of $0,0.8$, and $1.7 \mathrm{~kg} \cdot \mathrm{ha}^{-1} \mathrm{~B}$ to almond cv. Butte at one site (Parlier, Fresno County, Calif.), and of 0, 0.8, $1.25,1.7$, and $2.1 \mathrm{~kg} \cdot \mathrm{ha}^{-1} \mathrm{~B}$ on the same cultivar in August, September, or February at a second site (Orland, Glenn County, Calif.) using Borosol, a polyboronated commercial product containing $10 \%$ B. At site 1 , September application was more effective in increasing tissue B concentration, fruit set, and yield than were December or February applications. The optimal rate was 0.8 to $1.7 \mathrm{~kg} \cdot \mathrm{ha}^{-1} \mathrm{~B}$ when applied in September. At site 2, application in 1996 and 1997 increased tissue $B$ concentration almost linearly, especially when applied in August and February. Application at the highest rate $\left(2.1 \mathrm{~kg}^{\circ} \mathrm{ha}^{-1} \mathrm{~B}\right)$ in September produced the greatest final fruit set and yield in 1996. February applications increased initial fruit set at both sites but were less effective than September applications in increasing yield. Application of B did not affect any yield variable in 1997. These results suggest that B should be applied immediately postharvest (September) for optimal effect on tissue $B$ concentration, fruit set, and yield in almond.
\end{abstract}

Soil B is passively absorbed and transported through transpirational water flow $(\mathrm{Hu}$ and Brown, 1997; Pffefer et al., 1997; Raven, 1980). Environmental conditions, such as cold, rain, or drought, that lower mass flow in the soil, decrease diffusion and limit transpirational flow in the plant, thus resulting in B deficiency even when the supply of B in the soil is adequate. Boron deficiencies may also be transitory, occurring most commonly at times of rapid plant growth, especially during flowering and seed set in seed-producing crops. Thus, B deficiency in tree crops often occurs during the reproductive phase of growth and results in premature flower and fruitlet drop and, in severe cases, meristematic dieback (Brown et al., 1996; Shelp et al., 1995). The sensitivity of reproductive structures to B deficiency suggests either that movement of B to floral parts is restricted, or that the requirement for B for floral development and growth

Received for publication 2 Mar. 1998. Accepted for publication 18 Aug. 1998. The cost of publishing this paper was defrayed in part by the payment of page charges. Under postal regulations, this paper therefore must be hereby marked advertisement solely to indicate this fact. is higher than that required for vegetative growth. Given the specific requirement for B at flowering, fertilization practices that target this phase of plant growth should be developed.

The enhancement of yield by foliar B applications in perennial tree crops has long been recognized. Batjer and Thompson (1949) and Hanson et al. (1985) observed a proportionate increase in fruit set in 'Italian' prune (Prunus domestica) and 'Anjou' pear (Pyrus communis) with increasing concentration of foliar B, when applied before anthesis. Hanson (1991a, $1991 \mathrm{~b}$ ) reported as much as a $100 \%$ increase in fruit set in sour cherry (Prunus cerasus L.) following postharvest and prebloom foliar B applications. Under normal conditions, many almond cultivars have an average fruit set of only $22 \%$ to $30 \%$ (Kester and Griggs, 1959). In our experiments in Fresno, Calif. (Nyomora et al., 1997), fruit set of 'Butte' was increased $130 \%$, while yield was increased $53 \%$ by foliar application of B in the fall. Similar results were observed in both years of the study.

Previous studies in almond (Nyomora et al., 1997) and other Prunus sp. have not adequately considered the effect of timing of $B$ application on tree response. In this study we report on research conducted over a 3-year period at two sites in California. At each site, $\mathrm{B}$ was applied at three distinct dates.
Plant materials and treatment. Two orchards with low-B leaf concentration (22-24 $\mu \mathrm{g} \cdot \mathrm{g}^{-1}$ dry matter) were identified in Parlier, (Fresno County) and Orland (Glenn County), Calif. Adequate B levels for almond are considered to be $>30 \mu \mathrm{g} \cdot \mathrm{g}^{-1}$ dry matter (Shear and Faust, 1980). In Fresno County, the experiment was conducted on 15-year-old trees in 1994 on five-tree plots with five replications (plots) per treatment. Two rates that had previously been shown to have positive effects $(0.8$ and $1.7 \mathrm{~kg} \cdot \mathrm{ha}^{-1}$ B) (Nyomora et al., 1997) were tested using Solubor, a commercial product containing $20.5 \%$ B at a water volume of 3260 $\mathrm{L} \cdot \mathrm{ha}^{-1}$. In Fresno County, the treatments were applied to leaves on 30 Sept. 1993 (2 weeks after nut harvest), on 18 Dec. 1994 (dormant buds), and on 21 Feb. 1994 (flowers at popcorn stage) using a handgun sprayer. At the Glenn County site, rates of $0,0.8,1.25,1.7$, and $2.1 \mathrm{~kg} \cdot \mathrm{ha}^{-1} \mathrm{~B}$ were applied on 12 Aug. 1995 and 27 Aug. 1996 (5\% hull split); 25 Sept. 1995 and 30 Sept. 1996 (2 weeks after harvest); and 15 Feb. 1995, 1996, and 1997 (swollen flower buds). Borosol, a polyboronated commercial product containing $10 \% \mathrm{~B}$ was applied until runoff using a handgun sprayer at a rate of $15.2 \mathrm{~L} /$ tree, equivalent to an application rate of 3750 $\mathrm{L} \cdot \mathrm{ha}^{-1}$. Data were collected on tissue B concentration, fruit set, and yield at both sites.

Sampling methods and analysis of $B$. Twenty-five leaves were sampled in early fall prior to treatment and again $5 \mathrm{~d}$ after application (except for December application when there were no leaves present), as well as during summer (June), from nonfruiting shoots and spurs around each treated tree. Leaves were washed in a mild liquid detergent and rinsed three times in double-deionized water before drying overnight at $65^{\circ} \mathrm{C}$. Dry leaves were ground ( $30 \mathrm{mesh}$ ) and samples of $\approx 0.5 \mathrm{~g}$ were ashed overnight at $500^{\circ} \mathrm{C}$. The ashed samples were digested (heated in $10 \mathrm{~mL} 1 \mathrm{~N}$ nitric acid at $80^{\circ} \mathrm{C}$ for $20 \mathrm{~min}$ ), then diluted to $50 \mathrm{~mL}$ with double-deionized water before analysis by inductively coupled plasma atomic emission spectroscopy (Thermo Jarrell Ash, Menlo Park, Calif.). The same preparation and digestion procedures were used for the flower buds [ 250 $\mathrm{g}$ fresh weight $(\mathrm{FW})]$, flowers (100 g FW), pistils (200 g FW), and immature fruit (10) samples. Flower bud samples were collected from treated and nontreated trees in January/ February, flowers in mid-February, and immature fruits in mid-May. Ten-nut subsamples were randomly selected from the $1.8-\mathrm{kg}$ subsamples of mature fruit taken from each treatment at harvest, separated into hulls, shells, and kernels, and analyzed for B in a manner similar to that used for immature fruit and leaf tissue. Boric acid calibration standards from the National Institute of Standards and Technology were used after every 10 to 15 samples were analyzed.

Statistical analyses. Statview and Superanova software (Abacus Concepts, Berkeley, Calif.) was used to perform analysis of variance and obtain standard errors for mean separation $(5 \%)$. 


\section{Fresno County}

Leaf B concentration. Rate and time of B application had significant effects on B concentration in all plant tissues (Fig. 1A-D). However, for most tissue types, no significant differences were observed between the two rates of $\mathrm{B}\left(0.8\right.$ and $\left.1.7 \mathrm{~kg} \cdot \mathrm{ha}^{-1}\right)$. Leaf and hull samples from trees sprayed in February had significantly higher B concentrations than those sprayed with $0.8 \mathrm{~kg} \cdot \mathrm{ha}^{-1}$ in September and December (Fig. 1 A and B). Boron concentration in immature fruit was highest in trees sprayed in September and lowest in those sprayed in December at both rates of application (Fig. 1C). Kernel B concentration tended to increase with increasing rates of $\mathrm{B}$ application irrespective of the time of B application (Fig. 1D), but rate of application had no significant effect (Fig. 1D). High variations in tissue $\mathrm{B}$ concentration were found in samples from trees treated with the highest rate of $\mathrm{B}$.

Fruit set. Generally, the initial and final nut sets were significantly correlated with the rate of B application (Fig. 2 A and B). The initial fruit set was higher in trees sprayed in February than in those sprayed in September (Fig. 2A), with the December treatment having an intermediate effect, but differences between the two rates of B were insignificant. Foliar B application was more effective in February or September than in December (Fig. 2B). Final fruit set exceeded $25 \%$ when $0.8 \mathrm{~kg} \cdot \mathrm{ha}^{-1} \mathrm{~B}$ was applied in February, but a rate of $1.7 \mathrm{~kg} \cdot \mathrm{ha}^{-1}$ was required to achieve a similar fruit set when applied in September. The dormant spray in December did not affect the final set. Applying $1.7 \mathrm{~kg} \cdot \mathrm{ha}^{-1}$ was less effective in February than in September.

Yield. Boron applied in September at both rates increased nut number (Fig. 2C) and weight (Fig. 2D), whereas only the higher rate was effective in December or February. Treated trees yielded $>12,000$ nuts weighing $35 \mathrm{~kg}$ (inshell nuts) per tree, while controls yielded only $\approx 6000$ nuts weighing $<17 \mathrm{~kg}$ (inshell nuts) per tree. No difference in yield (number and weight) was observed between the two B rates $\left(0.8\right.$ and $\left.1.7 \mathrm{~kg} \cdot \mathrm{ha}^{-1}\right)$ following applications in September.

\section{Glenn County}

Tissue B concentration. Both time and rate of application had a significant effect on leaf, bud, and hull B concentration (Fig. 3A-D). Similar results were obtained in 1996 and 1997, so only data for 1997 are presented. No significant differences in $\mathrm{B}$ concentration were observed in immature and mature fruit samples as a result of any treatment (data not shown).

Leaf B concentration in leaves harvested in June and Sept. 1997 was highest (from 35 to $>45 \mathrm{mg} \cdot \mathrm{kg}^{-1}$ ) when trees were sprayed in Feb. 1997 than when sprayed in Sept. or Aug. 1996 (Fig. 3 A and B). Boron applied in August significantly increased B levels in leaves sampled in June (Fig. 3A) or Sept. 1997 (Fig. 3B) only when applied at the highest rates. Similar results were found in the 1995-96

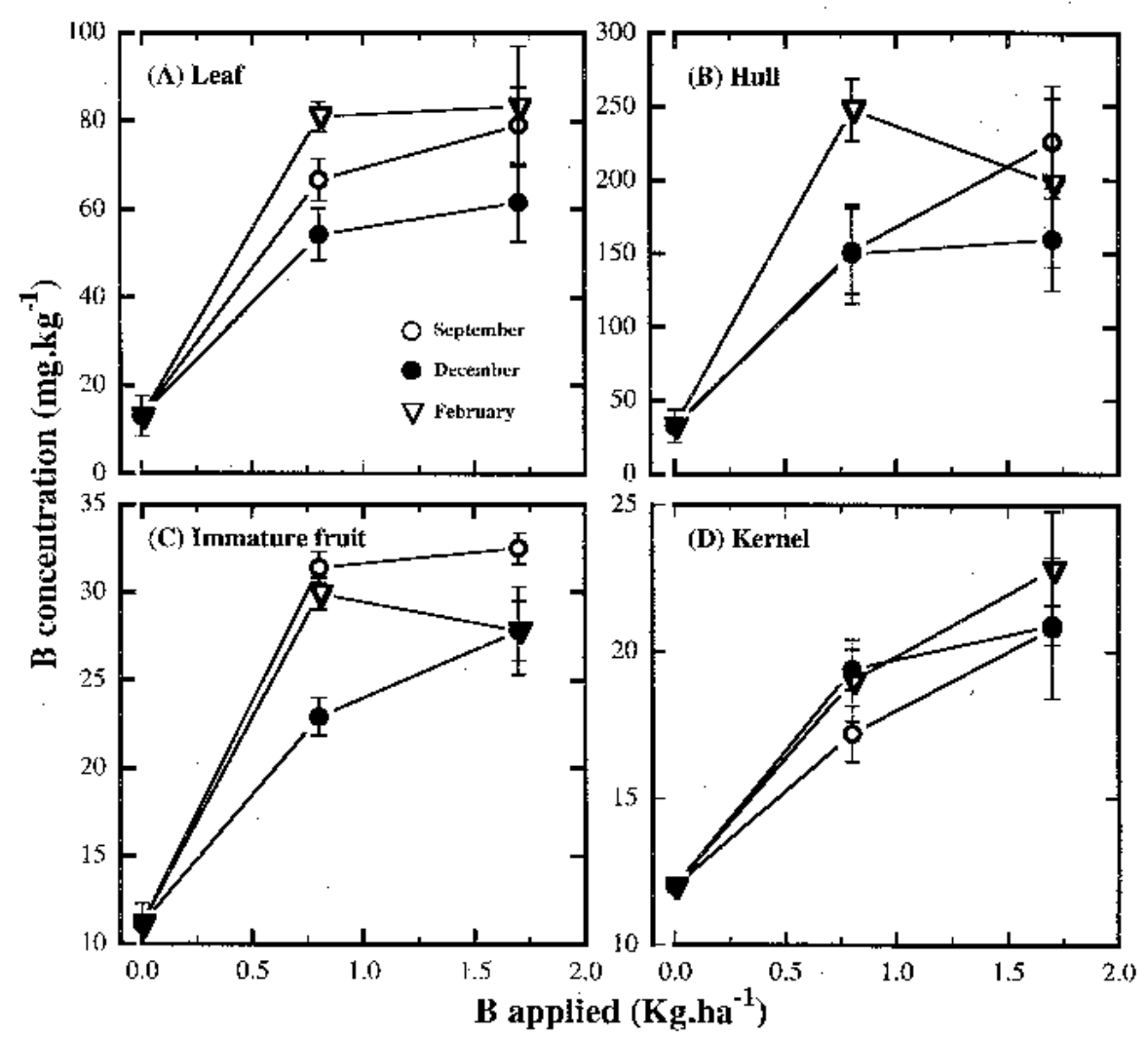

Fig. 1. Tissue B concentration in almond cv. Butte in response to B sprays applied at indicated times (September, December, and February) (Fresno site). (A) Leaf sampled in June following December application, and $5 \mathrm{~d}$ after application for September and February treatments; (B) hull; (C) immature fruit; (D) kernel. Each data point and corresponding standard error bar represent the mean for five replications. Note that values of $\mathrm{B}$ on ordinate differ among graphs.

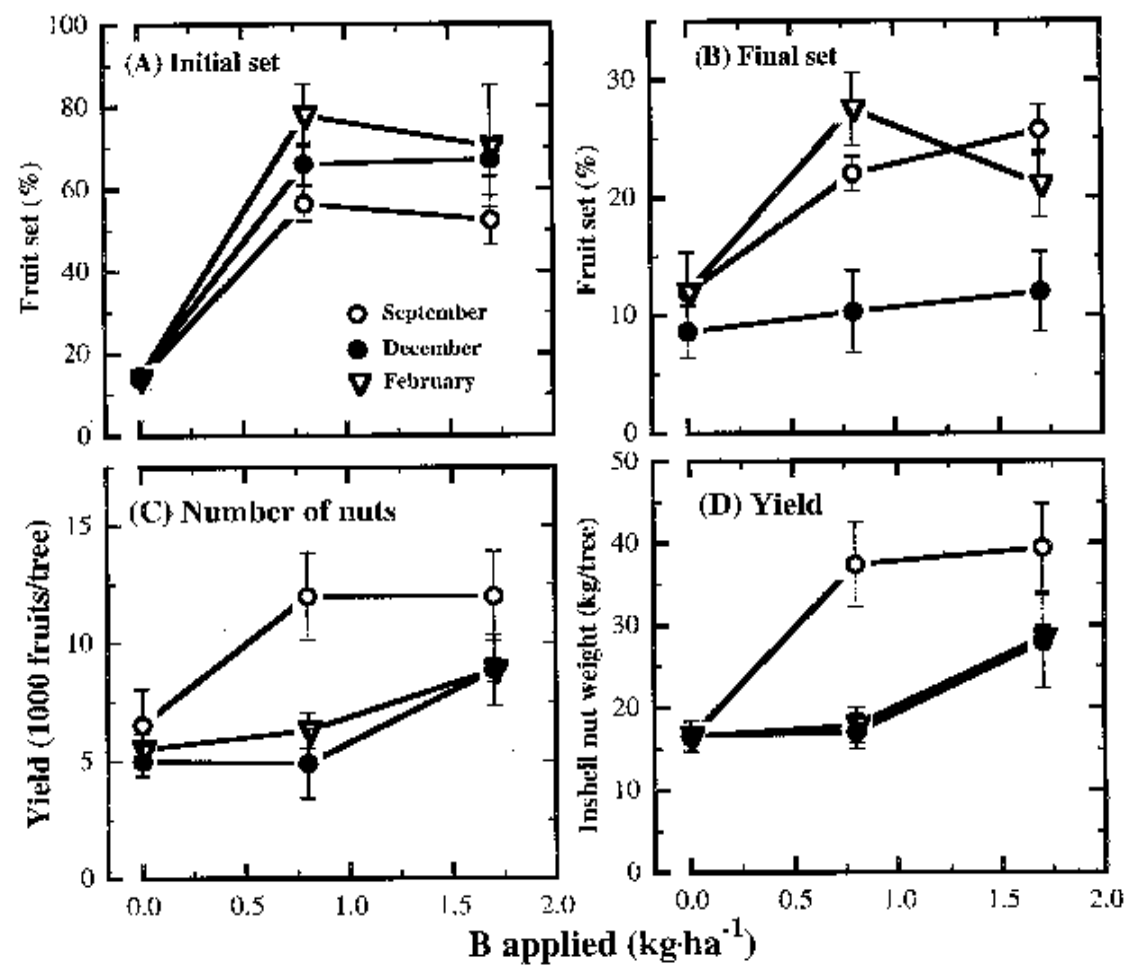

Fig. 2. Effects of rates and times of foliar B application on almond cv. Butte nut set and yield (Fresno site). (A) Initial set; (B) final set; (C) number of nuts, (D) inshell nut weight (yield). Each data point and corresponding standard error bar represents the mean for five replications. 
season (data not shown). Bud B concentration increased significantly from $80 \mathrm{mg} \cdot \mathrm{kg}^{-1}$ in nontreated trees to $>150 \mathrm{mg} \cdot \mathrm{kg}^{-1}$ in trees sprayed with $2.1 \mathrm{~kg} \cdot \mathrm{ha}^{-1}$ (Fig. 3C). Application in February was more effective than in August or September (Fig. 3C). Hull B concentration increased from $100 \mathrm{mg} \cdot \mathrm{kg}^{-1}$ in nontreated trees to $>300 \mathrm{mg} \cdot \mathrm{kg}^{-1}$ in trees treated with $1.7 \mathrm{~kg} \cdot \mathrm{ha}^{-1}$ when trees were sprayed in Aug. 1997 and sampled the following month (Fig. 3D). Hull B concentration in 1997 was not affected by sprays applied in Sept. 1996.

Fruit set. Cold temperatures and heavy rain during the flowering period reduced fruit set in 1996. Nevertheless, timing and rate of B application influenced the initial (Fig. 4A) and final fruit set (data not shown). Initial fruit set increased with increasing concentration of B applied in both Aug. 1995 and Feb. 1996, but was only marginally affected by treatment in Sept. 1995 (Fig. 4A). In 1996, the highest initial fruit set was recorded in trees sprayed in February. The weather was excellent for almond production in 1997 in Orland (Glenn County), and B treatment did not affect fruit set.

Yield. Some increases in yield due to different times of application were observed in 1996 (Fig. 4 B and C). When applications were made in Sept. 1995 and Feb. 1996, number and weight of nuts per tree increased with increasing $\mathrm{B}$ concentration, and was maximum at 2.1 $\mathrm{kg} \cdot \mathrm{ha}^{-1}$ (Fig. $4 \mathrm{~B}$ and C). In contrast, B application in August was ineffective.

\section{Discussion}

The timing of foliar B application significantly influenced almond response to the micronutrient. In general, applications made in September were more effective than those made in February or December, probably because there was no foliage on the trees in December. This suggests that dormant buds are inefficient at absorbing applied B. Hanson and Breen (1985) also noted that little B moved into dormant prune buds prior to bud swell. They observed a rapid accumulation of $\mathrm{B}$ in flower buds in March as bloom approached, concurrent with substantial xylem differentiation in the bud axil.

Brown and coworkers (Brown and $\mathrm{Hu}$ 1996; Brown and Shelp, 1997, and references therein) have recently determined that $B$ transport in the phloem occurs as a consequence of the formation of a B-polyol complex in mature leaves of Prunus and transport of that complex to currently active sink organs. Hence, the presence of active sinks, such as buds and fruits, also plays an important role in determining net B movement in Prunus species (Brown and Shelp, 1997). Similarly, Delgado et al. (1994) found higher B concentrations in young than in old olive leaves, and in young leaves subtended by fruits than in similar leaves from nonbearing trees. Here, we observed no effect of rate of B application on B concentration when applications were made in August when hulls were only $5 \%$ split. We speculate that the fruits are still actively metabolizing, hence most of the B applied to the foliage in

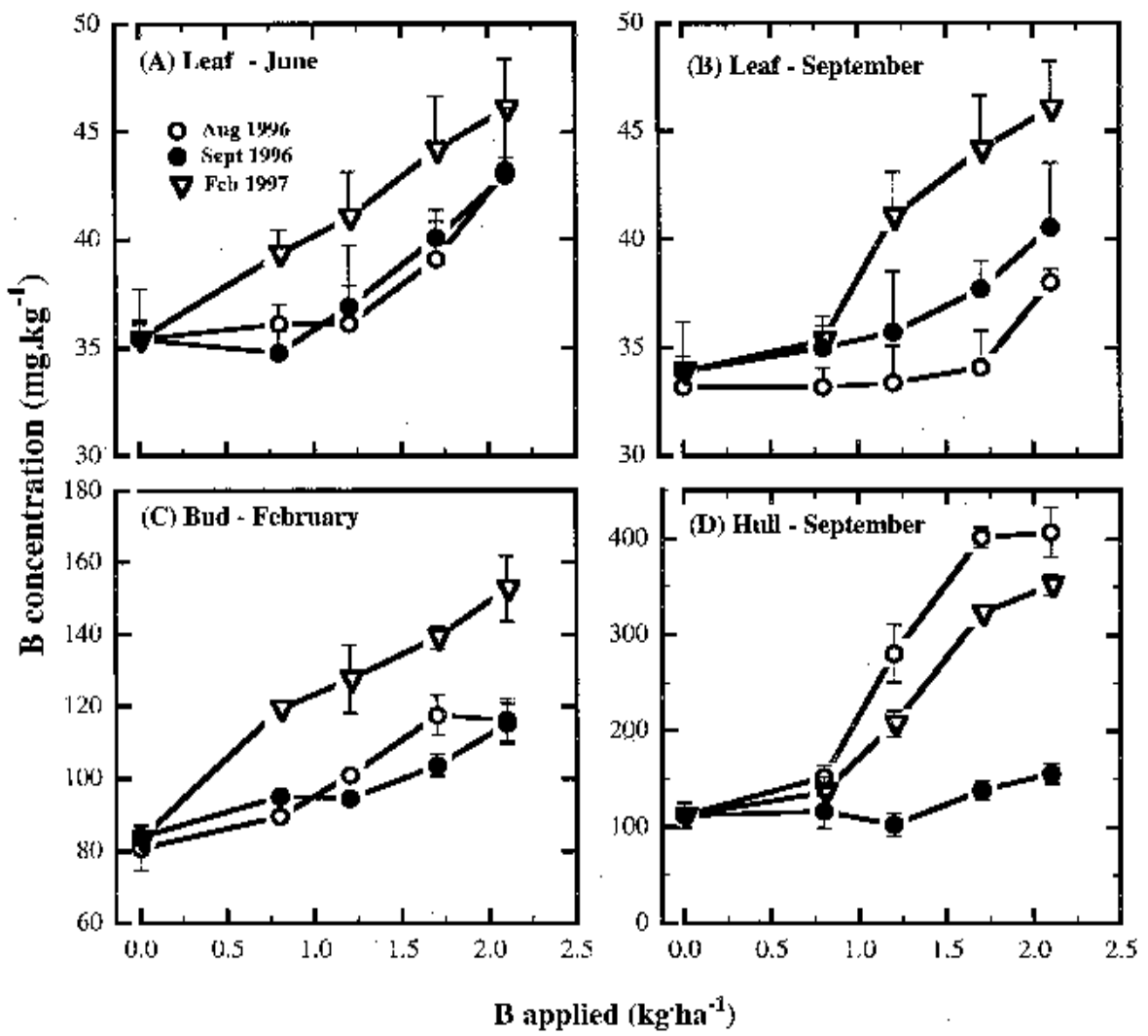

Fig. 3. Tissue B concentration in almond cv. Butte in response to foliar B sprays applied at indicated times (August, September and February) in Glenn County. (A) Leaf B in June; (B) leaf B in September; (C) bud B in February; (D) hull B in September. Each data point and corresponding standard error bar represent the mean for five replications. Error bars, if not visible, are smaller than the symbol. Note that values of $\mathrm{B}$ on ordinate differ among graphs.

August is translocated to the fruits. This is evidenced by the higher hull B concentrations in samples harvested from trees that were sprayed at this time (Fig. 3D). If B is applied while fruit are still on the tree, it should be applied closer to harvest, when fruits are mature, to avoid competition between fruits and buds for available B.

In 1996, fruit set was significantly higher in sprayed than in nonsprayed trees and trees sprayed with the highest rate of B in February exhibited the highest initial and final set. Yield, as both number and weight of the fruits, on the other hand, was greatest in trees sprayed in Sept. 1996 in Glenn County. The results of this experiment confirm the positive benefits of foliar B on tissue B concentration, nut set, and yield described previously (Nyomora et al., 1997), and also confirm findings that fall applied B is optimal in other Prunus species (Callan et al., 1978).

Even though positive responses to foliar B applications have now been observed in almond at several sites and in several years, yields were not significantly increased by time or rate of foliar B application in 1997. High variation among trees contributed to the insignificant treatment effects, but the possibility of a residual effect of B cannot be ruled out. These results, however, are not unusual and reflect the fact that crop response to foliar B is variable. For example, Boaretto et al. (1997) reported that leaf $\mathrm{B}$ concentration of citrus increased linearly with higher rates of B appli- cation but there was no corresponding increase in fruit yield. Smith et al. (1997) sprayed avocado (Persea americana Mill. 'Hass') at fully developed panicle stage and observed a $42 \%$ increase in fruit set but no significant increase in fruit retention. Spraying panicles at earlier stages of development had no detectable effect on either fruit set or fruit retention. Callan et al. (1978) consistently observed increased fruit set, but not increased yield, in 'Italian' prunes in response to foliar B sprays, while Bramlage and Thompson (1962) observed no increase in fruit set of apple (Malus $\times$ domestica Borkh.) after spraying B during blossoming or petal fall. On the other hand, Baron $(1968,1973)$ reported yield increases of between $10 \%$ and $88 \%$, and Shrestha et al. (1987) reported a $17 \%$ to $21 \%$ yield increase in 'Barcelona' hazelnuts (Corylus avellana L.). Nyomora et al. (1997) reported a maximum of $130 \%$ increase in fruit set of 'Butte' almond and $53 \%$ increase in yield in response to foliar application of B in the fall. Crop response to B is variable and there is no clear relationship between tissue B and yield response. Nevertheless, in many years, very significant responses to foliar B do occur.

Foliar B applications resulted in increased initial fruit set in 2 of 3 years (Figs. 2-4), as well as in our previous experiments (Nyomora, 1997), thus providing the potential for increased yield. Response to B application appears to be minimal in years when fruit set is good. Although an increase in set should in- 

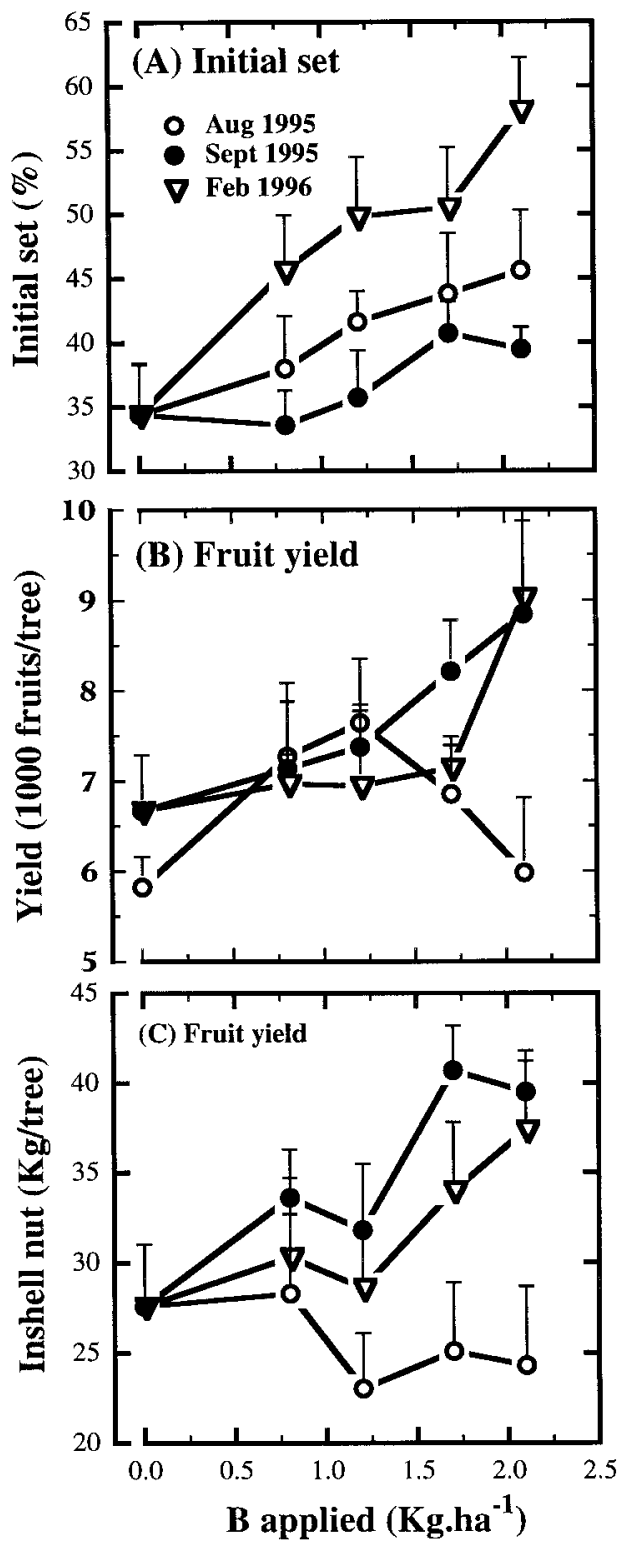

Fig. 4. Effects of rates and times of foliar B application on almond cv. Butte (A) initial fruit set and (B and C) yield in 1996 (Glenn County). Each data point and corresponding standard error bar represent the mean for five replications.

crease yield, yields are not always increased, as other unknown factor(s) may ultimately determine the percentage of fruit that remain on the tree at harvest. Environmental conditions, plant species and genotypes, cropping level, fruit size, interaction of $\mathrm{B}$ with other nutrients, as well as time of B application, have been reported to influence tree responses to applied B. Reports include those of Baron (1973) for hazelnut, Batjer and Thompson (1949) and Shrestha et al. (1987) for pears, Delgadoetal.(1994) for olives, Hanson(1991a, 1991b) for prune, and Shu et al. (1994) for peach. The environmental conditions at the time of application differ with site, season, and tree canopy in the orchard and can account for some of the inconsistencies found in relating foliar B application to fruit set and yield in this study. Unfortunately, the strong environmental interactions coupled with our inadequate knowledge of the role of $\mathrm{B}$ in reproduction do not allow us to accurately predict when foliar
Batjer, L.P. and A.H. Thompson. 1949. Effects of boric acid sprays applied during bloom upon the set of pear fruits. Proc. Amer. Soc. Hort. Sci. 53:141-142.

Boaretto, A.E, C.S. Tiritan, and T. Muraoka. 1997. Effects of foliar applications of boron on citrus fruit and on foliage and soil boron concentration, p. 121123. In: R.W. Bell and B. Rerkasem (eds.). Boron in soils and plants. Kluwer Academic, The Netherlands.

Bramlage, W.J and A.H. Thompson. 1962. The effects of early-season sprays of boron on fruit set, color, finish and storage life of apples. Proc. Amer. Soc. Hort. Sci. 80:64-72.

Brown, P.H. and H. Hu. 1996. Phloem mobility of boron is species dependent. Evidence for phloem mobility in sorbitol rich species. Ann. Bot. 77:497-505.

Brown, P.H., H. Hu, A. Nyomora, and M. Freeman. 1996. Foliar application enhances almond yields. Better crops with plant food, no.1. Potash and Phosphate Inst. Ref. No. 323054/95223.

Brown, P.H. and B.J. Shelp. 1997. Boron mobility in plants. Plant Soil 193:85-101.

Brown, P.H. and K. Uriu. 1997. Nutritional deficiencies and toxicities in walnut: Diagnosing and correcting imbalances, p. 187-196. In: Walnut production manual. Univ. of California, Div. of Agr. and Nat. Research. Publ. \#3373.

Callan, N.W., M.M. Thompson, and M.N. Westwood. 1978. Effects on fruit set of Italian prune following fall foliar and spring B sprays. J. Amer. Soc. Hort. Sci. 103:253-257.

Delgado, A., M. Benlloch, and R. Fernandez-Escobar. 1994. Mobilization of boron in olive trees during flowering and fruit development. HortScience 29:616-618.

Hanson, E.J. 1991a. Movement of boron out of tree fruit leaves. HortScience 26:271-273.

Hanson, E.J. 1991b. Boron requirement and mobility in tree fruit species. Current Topics in Plant Biochem. Physiol. 10:240-246.

Hanson, E.J. and P.J. Breen. 1985. Xylem differentiation and boron accumulation in Italian prune flower buds. Proc. Amer. Soc. Hort. Sci. 110:566-570.

Hanson, E.J., M.H. Chaplin, and P.J. Breen. 1985. Movement of foliar applied boron out of leaves and accumulation in flower buds and flower parts of 'Italian' prune. HortScience 20:747-748.

Hu, H. and P.H. Brown. 1997. Absorption of boron by plant roots. Plant Soil 193:49-58.

Kester, D.E. and W.H. Griggs.1959. Fruit setting in almonds: The pattern of flower and fruit drop. J. Amer. Soc. Hort. Sci. 74:214-219.

Martini, F and M. Thellier. 1980. Use of an (n, $\alpha)$ nuclear reaction to study the long-distance transport of boron in Trifolium repens after foliar application. Planta 150:197-205.

Nyomora, A.M.S., P.H. Brown, and M. Freeman. 1997. Fall foliar-applied boron increases tissue boron concentration and nut set of almond. J. Amer. Soc. Hort. Sci. 122:405-410.

Pfeffer, H., F. Dannel, and V. Römheld. 1997. Compartmentation of boron in roots and its translocation to the shoot of sunflower as affected by short term changes in boron supply, p. 203-207. In: R.W.Bell and B. Rerkasem (eds.). Boron in soils and plants. Kluwer Academic, The Netherlands.

Raven, J.A. 1980. Short- and long-distance transport of boric acid in plants. New Phytol. 84:231-249.

Shear, C.B. and M. Faust.1980. Nutritional ranges in deciduous tree fruits and nuts. Hort. Rev. 2:142-163.

Shelp, B.J., E. Marentes, A.M. Kitheka, and P. Vivekanandan. 1995. Boron mobility in plants. Physiol. Plant. 94:356-361.

Shrestha, G.K., M.M. Thompson, and T.L. Righetti. 1987. Foliar-applied boron increases fruit set in 'Barcelona' hazelnut. J. Amer. Soc. Hort. Sci. 112:412-416.

Smith, T.E, R.A. Stephenson, C.J. Asher, and S.E. Hetherington. 1997. Boron deficiency in avocado. 1.Effects on pollen viability and fruit set, p. 131133. In: R.W. Bell and B. Rerkasem (eds.). Boron in soils and plants. Kluwer Academic, The Netherlands. 